\title{
Immunocytochemical Localization of Bovine Serum Albumin (BSA) in the Liver and Testis of Rats injected with Testosterone-BSA, Hydrocortisone-BSA or Corticosterone-BSA
}

\author{
Toshikazu Nishimura* and Takashi Nakano \\ Department of Anatomy, Aichi Medical University, Yazako, Nagakute-cho, Aichi-gun, Aichi-ken 480-1195, \\ Japan
}

\begin{abstract}
Through observations of colloidal gold with silver enhancement, we have demonstrated that 2-nm colloidal gold labeled-testosterone-bovine serum albumin (BSA) conjugate or hydrocortisone-BSA conjugate injected intravenously enters the hormone-target cell nuclei of rats (Nishimura and Ichihara, 1997; Nishimura and Nakano, 1997, 1999). To confirm immunocytochemically whether the nature of BSA in the steroid hormone-BSA conjugates (steroid-BSAs) remains intact in the hormone-target cell nuclei, testosterone-BSA, hydrocortisone-BSA or corticosterone-BSA was injected into the vascular system of rats, then the liver and testes of rats killed 2 h postinjection were reacted with FITC-conjugated anti-BSA antibody, and examined under fluorescence microscopy and confocal laser scanning microscopy. In the liver of rat injected with testosterone-BSA, the fluorescence was observed in the nuclei of endothelial cells, but not in the nuclei of hepatocytes, hepatic stellate cells and Kupffer cells. In the liver of rat injected with hydrocortisone-BSA, intense fluorescence was seen in the nuclei of hepatic stellate cells, but did not seem to be present in the nuclei of the other three kinds of cells. In the liver of rat injected with corticosterone-BSA, the fluorescence seemed to be in a few nuclei of hepatic stellate cells, and appeared as speckles in a few nuclei of the hepatocytes and Kupffer cells. In some seminiferous tubules of rat injected with testosterone-BSA, fluorescence was observed in the nuclei of spermatocytes and spermatids. These results suggest that BSA conjugated with steroid hormone can enter the hormone-target cell nuclei with its antigenicity kept intact, and that the fate of steroid-BSAs is decided at the cell membrane level.
\end{abstract}

Key words: testosterone-BSA/hydrocortisone-BSA/corticosterone-BSA/target cell nuclei/ in vivo/immunocytochemistry

Steroid hormones circulate in blood plasma in three physical states: free, albumin-bound, and bound to serum steroid binding proteins such as sex hormone-binding globulin (SHBG) and corticosteroid-binding globulin (CBG) (Kuhn, 1988; Pardridge, 1988; Pescovitz et al., 1990; Rosner et al., 1988). Radiolabeled steroid hormones, e.g., $\left[{ }^{3} \mathrm{H}\right]-$ testosterone, $\left[{ }^{3} \mathrm{H}\right]$-hydrocortisone and $\left[{ }^{3} \mathrm{H}\right]$-corticosterone, may enter the target cell nuclei in vivo (Beato et al., 1969; Csaba et al., 1970; Csaba and Fülöp, 1987; Murtazaeva et al., 1978; Sar et al., 1970, 1975). In the classic, or genomic model of steroid hormones, free lipophilic nonproteinbound hormones cross the cell membrane under passive

\footnotetext{
* To whom correspondence should be addressed:

Tel: +81-561-62-3311, Fax: +81-561-61-0324,

E-mail: nishimur@aichi-med-u.ac.jp

Abbreviations: BSA, bovine serum albumin; CBG, corticosteroid-binding globulin; SHBG, sex hormone-binding globulin; FDA, formaldehydedenatured albumin; FITC, fluorescein-isothiocyanate; LSM, confocal laser scanning microscope.
}

transport to bind to the receptor in the cytoplasm, and the hormone-receptor complex is translocated into the target cell nucleus to exert genomic effects (Bamberger et al., 1996; Guiochon-Mantel et al., 1996; Htun et al., 1996; Jensen and DeSombre, 1972; Madan and DeFranco, 1993; Mangelsdorf et al., 1995; Mendel, 1992). In contrast, steroid hormones conjugated with radioiodinated- or fluorescein-isothiocyanate (FITC)-labeled-bovine serum albumin (BSA) have been used in analyzing the binding sites of steroid hormones to cell membranes (Bergqvist et al., 1984; Ke and Ramirez, 1990; Pertschuk et al., 1980; Rao et al., 1980), because steroids coupled with highmolecular weight substances cannot pass through the cell membrane and do not enter the cytosol. Thus, steroids coupled with high-molecular weight substances, e.g. steroid hormone-BSA conjugates (steroid-BSAs), are also used to study the membrane-initiated or nongenomic activities of steroid hormones (Duval et al., 1983; Gametchu et al., 
1999; Revelli et al., 1998; Rosner et al., 1999; Rossato et al., 1999; Watson and Gametchu, 1999; Watson et al., 1999; Wehling, 1997).

Pietras and Szego (1984) have suggested that endocytotic vesicles serve as vehicles for the nuclear transfer of steroid hormones (Szego, 1984). Radiolabeled testosterone coupled with SHBG or androgen-binding protein is internalized by receptor-mediated endocytosis in spermatogenic cells, and then enters these cell nuclei in vitro (Gerard et al., 1991; Gerard, 1995; Gerard et al., 1994). CBG is also detected within the hormone-target cell nuclei (Kuhn, 1988; Rosner et al., 1988; Selcer and Leavitt, 1988). Gold labeled-steroidBSA binds to nuclear receptors in the sectioned cells (Beppu, 1989; Okuda et al., 1989). We have reported that 2-nm colloidal gold labeled-testosterone-BSA (testosterone-BSAgold) and gold labeled-hydrocortisone-BSA (hydrocortisone-BSA-gold) injected into rats enters the hormone-target cell nuclei (Nishimura and Ichihara, 1997; Nishimura and Nakano, 1997, 1999), and have also demonstrated the possibility that testosterone-BSA-gold taken up in the vesicle by receptor-mediated endocytosis can enter the nucleoplasm through the fusion of the vesicle membrane with the partial diaphragm in the nuclear envelope, without coming in direct contact with the cytosol (Nishimura and Nakano, 1997). A wide variety of macromolecules taken up by endocytosis are incorporated by lysosomes, or the Golgi apparatus, or both (Alberts et al., 1994; Claus et al., 1998; Olkkonen and Stenmark, 1997; Rothman and Wieland, 1996). Colloidal gold as a marker of BSA seems to be stable in the lysosome (Bright et al., 1997; Fengsrud et al., 1995; Yoshioka et al., 1994). Therefore, it is unclear whether or not the nature of BSA in testosterone-BSA-gold and hydrocortisone-BSAgold is maintained in the nucleus.

The nuclear concentration of testosterone-BSA-gold was observed mainly in spermatogenic cells, with few in hepatocytes (Nishimura and Ichihara, 1997), as reported in studies using radiolabeled testosterone (Sar et al., 1970, 1975). In contrast nuclear localization of hydrocortisone-BSA-gold was done in hepatocytes and hepatic stellate cells (Nishimura and Nakano, 1999). In control, there was little nuclear localization of colloidal gold labeled-BSA in these cells (Nishimura and Ichihara, 1997). Since hydrocortisone is not synthesized in rats, corticosterone acts as a glucocorticoid (Pescovitz et al., 1990). In the present study, we attempted to detect immunocytochemically the location of BSA in the liver and the testis of rats injected with no gold labeledtestosterone-BSA, hydrocortisone-BSA or corticosteroneBSA conjugate (corticosterone-BSA), by using the antibody against the BSA.

\section{Materials and Methods}

\section{Materials}

Testosterone-3-o-carboxymethyloxime-bovine serum albumin conjugate (29 mols steroid per mole albumin, testosterone-BSA), hydrocortisone 21-hemisuccinate-bovine serum albumin conjugate (21 mols steroid per mole albumin, hydrocortisone-BSA) and corticosterone 21-hemisuccinate-bovine serum albumin conjugate (23 mols steroid per mole albumin, corticosterone-BSA) were purchased from Sigma (St. Louis, MO, USA). Anti-bovine serum albumin rabbit serum (anti-BSA serum) was purchased from Biogenesis (Poole, England). FITC-conjugated rabbit anti-bovine serum albumin antibody (anti-BSA antibody-FITC) was purchased from Inter-Cell Technologies, Inc. (Hopewell, NJ, USA).

\section{Pretreatment of antibody}

To get the normal rat liver- and testis-powder, livers and testes removed from normal rats were homogenized and freeze-dried. Anti-BSA antibody-FITC of $0.5 \mathrm{ml}$ was stirred with $20 \mathrm{mg}$ of normal rat liver- or testis-powder for $1 \mathrm{~h}$ at freezing temperature, then centrifuged at $10,000 \mathrm{~g}$ for $1 \mathrm{~h}$ at $4^{\circ} \mathrm{C}$. The supernatants were used as the antibody for the liver or testis, respectively.

\section{Administration of testosterone-BSA to rat}

Testosterone-BSA was dissolved at $1 \mathrm{mg} / \mathrm{ml}$ in saline with $5 \%$ glycerol. Hydrocortisone-BSA or corticosterone-BSA was dissolved at $2 \mathrm{mg} / \mathrm{ml}$ in saline with $5 \%$ glycerol. Rats (Wistar strain, male, 10 weeks old) were injected with $1 \mathrm{ml}$ testosterone-BSA, 1 $\mathrm{ml}$ hydrocortisone-BSA or $1 \mathrm{ml}$ corticosterone-BSA through the tail vein under ether anesthesia. After $2 \mathrm{~h}$, the rats were perfused with $30 \mathrm{ml}$ of saline, and then fixed by perfusion of paraformaldehyde fixative (4\% paraformaldehyde in $0.1 \mathrm{M}$ phosphate buffer, $\mathrm{pH}$ 7.4) for $10 \mathrm{~min}$ from the left to the right ventricle under ether anesthesia. The liver and testis were removed, cut into approximately $5-\mathrm{mm}$ blocks and immersed in the same fixative for $2 \mathrm{~h}$. The tissue blocks were washed with phosphate buffer, then immersed in phosphate buffer containing $15 \%$ sucrose overnight at $4^{\circ} \mathrm{C}$. The tissue blocks were frozen rapidly in liquid nitrogen, kept at $-80^{\circ} \mathrm{C}$, then sliced to a thickness of $5-\mu \mathrm{m}$.

\section{Control experiment}

The control rat, which received no injections, was fixed by perfusion as above. The liver and testis were removed, cut into pieces, fixed, and sectioned as above.

\section{Immunofluorescence staining}

The tissue sections were fixed with methanol for $20 \mathrm{~min}$, dried, and washed with Dulbecco's phosphate-buffered saline ( $\mathrm{PBS}^{-}$), for $5 \mathrm{~min}$. Sections were reacted with normal rabbit serum for $30 \mathrm{~min}$, then with the antibody for liver or testis for $2 \mathrm{~h}$ at room temperature, and washed with $\mathrm{PBS}^{-}$for $5 \mathrm{~min}$. The washing was repeated four times. Sections were stained with $0.01 \%$ Evans blue in $\mathrm{PBS}^{-}$ for $5 \mathrm{~min}$, washed with $\mathrm{PBS}^{-}$for $5 \mathrm{~min}$, and coverslides were mounted with PermaFluor Aqueous Mounting Medium (Shandon, Pittsburgh, PA, USA) for observation. Fluorescence images were obtained with a fluorescence microscope (Olympus, Tokyo, Japan) and a confocal laser scanning microscope (LSM-GB200: Olym- 
pus, Tokyo, Japan; LSM).

\section{Results}

It was first confirmed that anti-BSA serum reacted with testosterone-BSA, hydrocortisone-BSA, corticosterone-BSA and bovine serum, but not with rat serum, by Ouchterlony double-diffusion analysis (data not shown).

In the testis of the rat sacrificed $2 \mathrm{~h}$ after injection of testosterone-BSA, FITC fluorescence implying the presence of testosterone-BSA was observed in the locations of spermatocytes and spermatids in some seminiferous tubules (Fig. 1a). When the testis was observed under the LSM, the fluorescence was detected as being in the nuclei of the spermatocytes and the spermatids (Fig. 1b). In the liver, no fluorescence was observed in the nuclei of hepatocytes, hepatic stellate cells, or Kupffer cells. However, a few cells on the sinusoidal wall showed intense fluorescence under the fluorescence microscope (Fig. 2a). In some hepatocytes, the fluorescence was observed as many granules in the cytoplasm (Fig. 2b). Under the LSM, the fluorescence was detected as being in the nuclei of endothelial cells (Fig. 2c).

In the liver of the rat sacrificed $2 \mathrm{~h}$ after injection of hydrocortisone-BSA, intense fluorescence was seen in the nonparenchymal cells (Fig. 3a), and faint fluorescence in the hepatocytes, under the fluorescence microscope. Under the LSM, the intense fluorescence was found to be in the nuclei (Fig. 3b, c) and vesicles, or on the invaginated cell membrane (Fig. 3c) of hepatic stellate cells. The fluorescence in these nuclei was the most intense among all the cell nuclei examined in this study. No clear fluorescence was detected in the nuclei of endothelial cells (Fig. 3c). In the hepatocytes, fluorescence was also observed faintly in the cytoplasm and on the cell surface (Fig. 3c), but did not seem to be in the nucleus (Fig, 3b, c). In a very few Kupffer cells, faint fluorescence was detected in the cytoplasm, but did not seem to be in the nucleus (data not shown).

In the liver of rat sacrificed $2 \mathrm{~h}$ after injection of corticosterone-BSA, intense fluorescence was observed in some hepatocytes and nonparenchymal cells under fluorescence microscopy (Fig. 4a). However, the fluorescence in the nonparenchymal cells appeared weaker than that in the nuclei of the hepatic stellate cells of the rat injected with hydrocortisone-BSA. Under the LSM, intense fluorescence was observed as various granules in the cytoplasm of many cells, and as speckles in a few of the nuclei of hepatocytes (Fig. 4b). The fluorescence in the cytoplasm of the hepatocytes was more intense than that in rat injected with hydrocortisone-BSA. The immunostaining of nonparenchymal cells was divided into two patterns. In one, the fluorescence was found mainly in the cytoplasm and as speckles in a few nuclei (Fig. 4c). In the other, it was diffuse in the nucleus, but rare or nonexistent in the cytoplasm (Fig. 4d). The former pattern was detected in what appeared to be
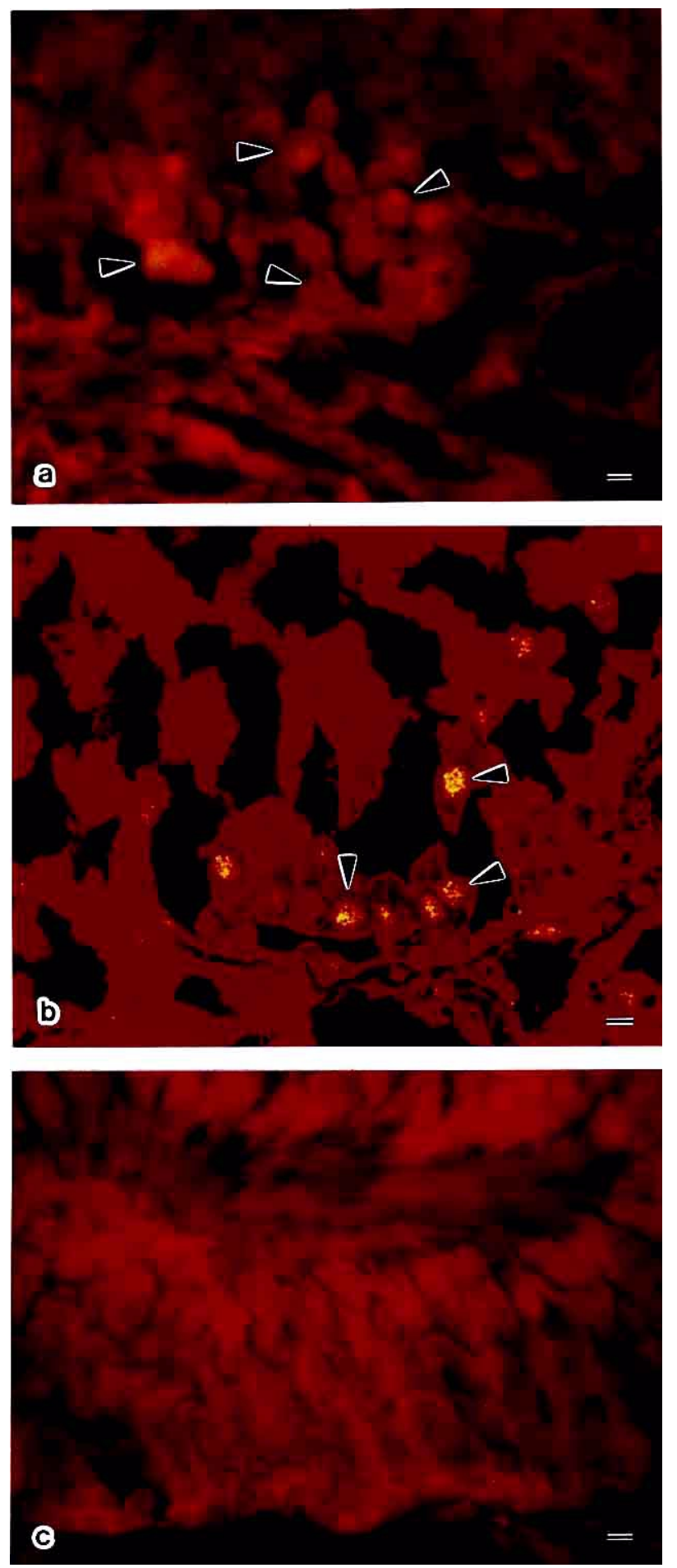

Fig. 1. Photographs under fluorescence microscope (a, c) and LSM GB200 single image (b) of the testes of rats injected with testosterone-BSA (a, b) or nothing (c). (a) The fluorescence (arrowheads) is seen in the locations of spermatocytes and spermatids. (b) The fluorescence (arrowheads) is seen as being in the nuclei of spermatocytes and spermatids. (c) No fluorescence is found. Bars $=10 \mu \mathrm{m}$. 

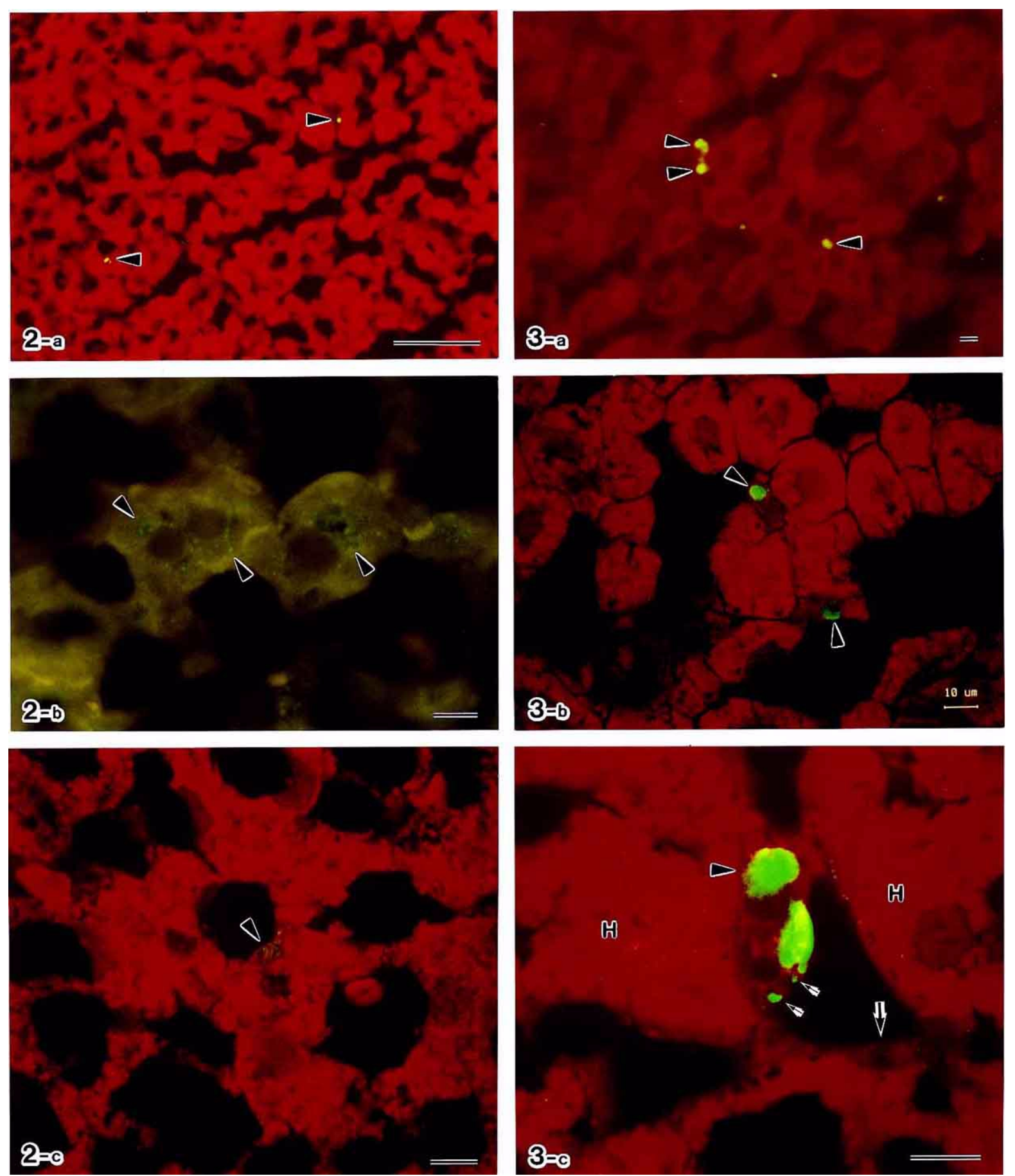

Fig. 2. Photographs under fluorescence microscope (a, b) and LSM GB-200 single image (c) of the liver of the rat injected with testosterone-BSA. (a) The fluorescence (arrowheads) is in two cells of the sinusoidal wall. (b) Highly magnified hepatocytes not stained with Evans blue. The fluorescence (arrowheads) is seen in the cytoplasm as many granules, but not in the nuclei. (c) The fluorescence (arrowhead) is in the nucleus of endothelial cell. Bars=(a) 100 $\mu \mathrm{m}$, (b) (c) $10 \mu \mathrm{m}$.

Fig. 3. Photographs under fluorescence microscope (a) and LSM GB-200 single image (b, c) of the liver of the rat injected with hydrocortisone-BSA. (a) The fluorescence (arrowheads) is intense in the nonparenchymal cells. (b) The fluorescence (arrowheads) is seen in the nuclei of hepatic stellate cells, but not in the hepatocyte nuclei. (c) The fluorescence is seen about the nuclear half (arrowhead) and the vesicles or invaginated cell membrane (small arrows) of hepatic stellate cell. In hepatocytes $(\mathrm{H})$, the fluorescence is present on the cell surface and in the cytoplasm faintly. No fluorescence is seen in the endothelial cell nucleus (large arrow). Bars $=10 \mu \mathrm{m}$. 

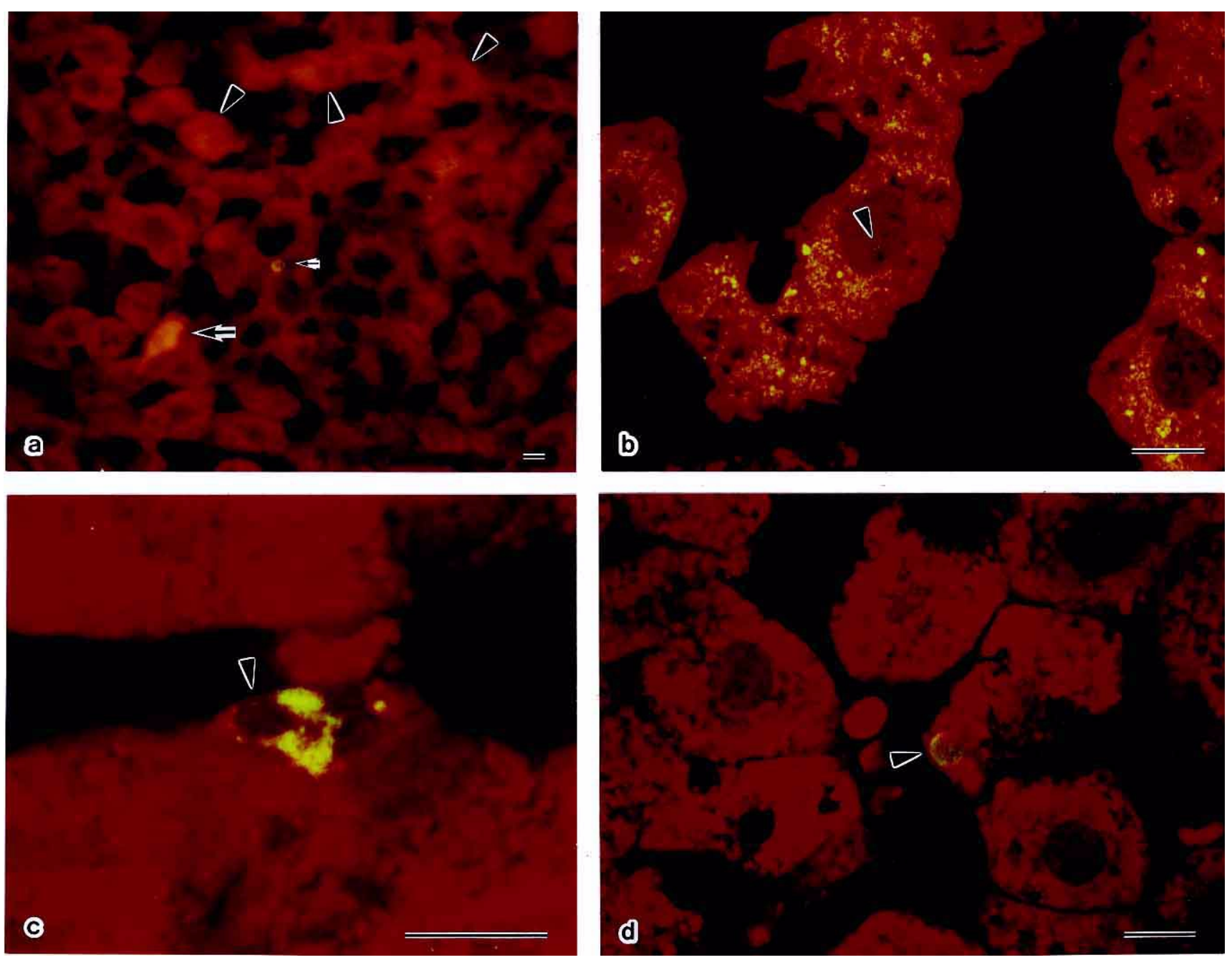

Fig. 4. Photographs under fluorescence microscope (a) and LSM GB-200 single image (b, c, d) of the liver of the rat injected with corticosterone-BSA. (a) The fluorescence is seen in some hepatocytes (arrowheads), throughout one entire nonparenchymal cell (large arrow), and in the nucleus of another nonparenchymal cell (small arrow). (b) Highly magnified hepatocytes. Many spots of fluorescence are seen in the cytoplasm, and two speckles are seen in the nucleus (arrowhead). (c) Highly magnified Kupffer cells. Intense fluorescence is seen in the cytoplasm, and one dot of fluorescence (arrowhead) in the nucleus. (d) Diffuse fluorescence (arrowhead) throughout the entire nucleus of what seems to be a hepatic stellate cell. Bars $=10 \mu \mathrm{m}$.

Kupffer cells, and the latter in hepatic stellate cells.

When the liver or the testis of the control rat, which received no injections, was reacted with the antibody for liver or for testis, no fluorescence was observed in the liver (not shown) or the cells in the seminiferous tubules (Fig. 1c) under either fluorescence or LSM-GB200 microscope.

\section{Discussion}

In previous studies in which testosterone-BSA-gold was injected into rats, silver deposits implying the presence of testosterone-BSA-gold were abundantly observed in the nuclei of spermatocytes and round spermatids in the target cells with silver enhancement (Nishimura and Ichihara, 1997; Nishimura and Nakano, 1997). The present study confirms the results of these previous studies, and suggests that testosterone-BSA enters the nuclei of spematocytes and spermatids with the antigenicity of BSA kept intact. However, further study is needed as to whether the antigenicity of BSA remains in other testosterone-target cells, e.g. spermatogonia, of the testis. Glucocorticoid receptors were detected in the nuclei of spermatocytes of rats (Schultz et al., 1993). Direct immunofluorescence in this study, however, did not reveal intense fluorescence in the spermatocyte nuclei of rats injected with hydrocortisone-BSA or corticosterone-BSA. Further study is need to determine whether or not hydrocortisone-BSA and corticosteroneBSA enter the spermatocyte nuclei.

Chemically modified serum albumin, such as formaldehyde-denatured albumin (FDA), is rapidly cleared from the 
bloodstream (Takami et al., 1992). The organ responsible for this is the liver. FDA is internalized by liver sinusoidal cells, such as Kupffer cells and endothelial cells, through a receptor-mediated endocytosis and is delivered to the lysosomal compartment (Mego et al., 1967; Nilsson and Berg, 1977; Yokota and Fahimi, 1987; Yoshioka et al., 1994). By contrast, normal serum albumin injected intravenously persists in the bloodstream of different animals for prolonged periods of time (Long et al., 1963; Owen et al., 1975). The nonparenchymal liver cells and endothelial cells of mouse liver do not take up injected BSA (Hope et al., 1981; Kosugi et al., 1992). In the present study, the results for the Kupffer cells of the rat injected with testosteroneBSA are compatible with our previous studies, in which little testosterone-BSA-gold was taken up by macrophages (Nishimura and Ichihara, 1997). Kupffer and endothelial cells have been shown to be devoid of immunoreactivity for glucocorticoid receptors in histological sections of rat liver (Antakly and Eisen, 1984), whereas, the present study shows that corticosterone-BSA enters the Kupffer cell nuclei. This result is compatible with a report that glucocorticoid receptor is present in the nuclei of isolated Kupffer cells (Raddatz et al., 1996), but incompatible with the result for hydrocortisone-BSA in the present study. Furthermore, this study shows that testosterone-BSA is incorporated in the endothelial cell nuclei. This result is supported by the reports that endothelial cells exhibit immunoreactivity for androgen receptors (Bläuer et al., 1991; Kimura et al., 1993; Liang et al., 1993). In this study, however, we failed to detect the intense fluorescence of hydrocortisone-BSA or corticosterone-BSA in endothelial cell nuclei that would indicate immunoreactivity for glucocorticoid receptors (Karstila et al., 1994). Though it is unclear whether Kupffer and endothelial cells take up the administered steroid-BSAs as steroid hormone, denaturated BSA or both, the existence of BSA in these cell nuclei indicates that these cells may recognize the steroid-BSAs as hormone, and it is possible that there is some mechanism that disturbs the digestion of steroid-BSAs by lysosomal enzymes. Estrogen is likely to decrease acidification of the early endosomes (Gay et al., 1993; Van Dyke and Root, 1993).

A synthetic glucocorticoid, dexamethasone, affects the gene expression of hepatic stellate cells isolated from rat liver (Ramadori et al., 1991). Hepatic stellate cell nuclei exhibit immunoreactivity for glucocorticoid receptors (Raddatz et al., 1996). This study confirms our previous report that the percentage of nuclei showing silver deposits, implying the presence of hydrocortisone-BSA-gold, was highest in hepatic stellate cells in rats injected with hydrocortisone-BSA-gold, and demonstrates that hydrocortisoneBSA enters the nuclei of the hepatic stellate cells with the antigenicity of BSA kept intact.

The liver is an organ of steroid hormone metabolism (Horton, 1990; Pescovitz et al., 1990). This study confirms our previous report that testosterone-BSA-gold is incorporated mainly in the cytoplasm of hepatocytes, with few in their nuclei (Nishimura and Ichihara, 1997). Serum proteins can be taken up by fluid-phase or receptor-mediated endocytosis by hepatocytes, and then recycled back to the basolateral membrane, degraded in lysosomes, or directed to bile (Crawford, 1996). In rat hepatocytes, radiolabeled BSA is taken up by fluid-phase endocytosis (Strømhaug et al., 1997), and the BSA injected intravenously is delivered into bile (Limet et al., 1985). Isolated rat hepatocytes also incorporate gold labeled-BSA in their lysosomes (Fengsrud et al., 1995). In contrast, this study shows that corticosterone-BSA is found in the nuclei of hepatocytes. This result is supported by reports that there are glucocorticoid receptors in the hepatocyte nucleus (Antakly and Eisen, 1984; Raddatz et al., 1996), that radioactivity of $\left[{ }^{3} \mathrm{H}\right]$-corticosterone is observed in the hepatocyte nucleus (Murtazaeva et al., 1978), and that the nuclear receptors in rat liver are specific for glucocorticoids, not testosterone (Shaskas and Bottoms, 1974). In this study, however, we failed to detect antigenicity of BSA conjugated with hydrocortisone in the hepatocyte nuclei. This result is incompatible with a previous report that hydrocortisoneBSA-gold enters the hepatocyte nuclei (Nishimura and Nakano, 1999). In the rat liver cell membrane, corticosterone exhibits higher binding affinity than hydrocortisone in competition experiments (Suyemitsu and Terayama, 1975; Truebe et al., 1991). The administration of estrogen to rats results in the intranuclear accumulation of lysosomal enzymes in steroid target cells such as cells of the preputial gland (Szego et al., 1974). Markers of BSA such as gold seem to be more stable during intracellular digestion than BSA. Intense fluorescence of hydrocortisone-BSA is observed in the nuclei of hepatic stellate cells, in which lysosomes are either very few or absent (Wake, 1980). Further study is needed to determine whether hydrocortisoneprotein conjugate enters the nuclei of the hepatocytes with its antigenicity kept intact.

Glucocorticoid receptor immunoreactive sites are associated with the plasma membrane and coated and regular vesicles in hippocampal and hypothalamic neurons of rat (Liposits and Bohn, 1993). Estrogen receptor- $\alpha$ tends to be found on the cell membrane of rat pituitary tumor cells (Norfleet et al., 1999). The present study also shows that the three kinds of steroid-BSAs exhibit different distributions in hepatocytes, Kupffer cells, hepatic stellate cells and endothelial cells. The observed distribution in the liver indicates that these four kinds of cells can distinguish between the difference in the three kinds of steroid-BSAs at the cell membrane level.

As stated above, this study suggests that a protein conjugated with steroid hormone retains its antigenicity in the target cell nuclei. A DNA virus, simian virus 40 (SV40), enters the nucleus by vesicle-mediated traffic (Nishimura et al., 1991) and maintains its original size (Hummeler et al., 
1970). Testosterone-BSA-gold enters the spermatid nucleus by a mechanism similar to that of SV40 (Nishimura and Nakano, 1997). The author considers that the vesicular trafficking from the extracellular milieu into the nucleus may play an important role in the processes of evolution. The next step is to confirm whether steroid hormones serve as a carrier to transport DNA into the nuclei of target cells, e.g. spermatogenic cells.

Acknowledgments. We would like to thank Dr. M. Kimura, T. Miyake, K. Arimura, J. Goto and Y. Nakagomi for their technical advice on photography and use of LSM, and Prof. S. Saga and colleagues of the Pathology Department for use of fluorescence microscope.

\section{References}

Alberts, B., Bray, D., Lewis, J., Raff, M., Roberts, K., and Watson, J.D. 1994. Vesicular traffic in the secretory and endocytic pathways. In Molecular Biology of Cell. 3rd ed. Garland Publishing, Inc. New York, pp. 599-651.

Antakly, T. and Eisen, H.J. 1984. Immunocytochemical localization of glucocorticoid receptor in target cells. Endocrinology, 115: 1984-1989.

Bamberger, C.M., Schulte, H.M., and Chrousos G.P. 1996. Molecular determinants of glucocorticoid receptor function and tissue sensitivity to glucocorticoids. Endocrine Rev., 17: 245-261.

Beato, M., Homoki, J., and Sekeris, C.E. 1969. On the mechanism of hormone action. X II. Uptake of $1,2-{ }^{3} \mathrm{H}-$ cortisol by isolated rat liver nuclei. Exp. Cell Res., 55: 107-117.

Beppu, K. 1989. An electron microscopic study of the steroid hormone receptor in uterine cells by the colloidal gold-labeled steroid hormone. $J$. Electron Microsc., 38: 430-440.

Bergqvist, A., Carlström, K., and Ljungberg, O. 1984. Histochemical localization of estrogen and progesterone receptors: Evaluation of a method. J. Histochem. Cytochem., 32: 493-500.

Bläuer, M., Vaalasti, A., Pauli, S. -L., Ylikomi, T., Joensuu, T., and Tuohimaa, P. 1991. Location of androgen receptor in human skin. $J$. Invest. Dermatol., 97: 264-268.

Bright, N.A., Reaves, B.J., Mullock, B.M., and Luzio, J.P. 1997. Dense core lysosomes can fuse with late endosomes and are re-formed from the resultant hybrid organelles. J. Cell Sci., 110: 2027-2040.

Claus, V., Jahraus, A., Tjelle, T., Berg, T., Kirschke, H., Faulstich, H., and Griffiths, G. 1998. Lysosomal enzyme trafficking between phagosomes, endosomes, and lysosomes in J774 macrophages. Enrichment of cathepsin H in early endosomes. J. Biol. Chem., 273: 9842-9851.

Crawford, J. M. 1996. Role of vesicle-mediated transport pathways in hepatocellular bile secretion. Semin. Liver Dis., 16: 169-189.

Csaba, G., Kiss, J., and Oláh, I. 1970. Mechanism of the formation of mast-cell granules. IV. Electron microscope radioautographic studies with ${ }^{3}$ H-hydrocortisone. Acta Biol. Acad. Sci. Hung., 21: 85-90.

Csaba, G. and Fülöp, A.K. 1987. Localisation of ${ }^{3} \mathrm{H}$-corticosterone inside thymocytes at different stages of ontogenetic development. $J$. Submicrosc. Cytol., 19: 567-571.

Duval, D., Durant, S., and Homo-Delarche, F. 1983. Non-genomic effects of steroids. Interactions of steroid molecules with membrane structures and functions. Biochim. Biophys. Acta, 737: 409-442.

Fengsrud, M., Roos, N., Berg, T., Liou, W., Slot, J.W., and Seglen, P.O. 1995. Ultrastructural and immunocytochemical characterization of autophagic vacuoles in isolated hepatocytes: Effects of vinblastine and asparagine on vacuole distributions. Exp. Cell Res., 221: 504-519.

Gametchu, B., Chen, F., Sackey, F., Powell, C., and Watson, C.S. 1999. Plasma membrane-resident glucocorticoid receptors in rodent lymphoma and human leukemia models. Steroids, 64: 107-119.

Gay, C.V., Kief, N.L., and Bekker, P.J. 1993. Effect of estrogen on acidification in osteoclasts. Biochem. Biophys. Res. Commun., 192: 12511259.

Gerard, A., En Nya, A., Egloff, M., Domingo, M., Degrelle, H., and Gerard, H. 1991. Endocytosis of human sex steroid-binding protein in monkey germ cells. Ann. N. Y. Acad. Sci., 637: 258-276.

Gerard, A. 1995. Endocytosis of androgen-binding protein (ABP) by spermatogenic cells. J. Steroid Biochem. Mol. Biol., 53: 533-542.

Gerard, H., Gerard, A., En Nya, A., Felden, F., and Gueant, J.L. 1994. Spermatogenic cells do internalize Sertoli androgen-binding protein: A transmission electron microscopy autoradiographic study in the rat. Endocrinology, 134: 1515-1527.

Guiochon-Mantel, A., Delabre, K., Lescop, P., and Milgrom, E. 1996. Intracellular traffic of steroid hormone receptors. J. Steroid Biochem. Mol Biol., 56: 3-9.

Hope, U., Schaefer, H.E., Hess, G., and Meyer zum Büschenfelde, K.H. 1981. In vivo uptake of immune complexes by parenchymal and nonparenchymal liver cells in mice. Gastroenterology, 80: 250-259.

Horton, R.J. 1990. Testicular steroid transport, metabolism, and effects. In Principles and Practice of Endocrinology and Metabolism (K.L. Becker, ed.). J.B. Lippincott Company, Philadelphia, pp. 937-942.

Htun, H., Barsony, J., Renyi, I., Gould, D.L., and Hager, G.L. 1996. Visualization of glucocorticoid receptor translocation and intranuclear organization in living cells with a green fluorescent protein chimera. Proc. Natl. Acad. Sci. USA, 93: 4845-4850.

Hummeler, K., Tomassini, N., and Sokol, F. 1970. Morphological aspects of the uptake of simian virus 40 by permissive cells. J. Virol., 6: 87-93.

Jensen, E.V. and DeSombre, E.R. 1972. Mechanism of action of the female sex hormones. Annu. Rev. Biochem., 41: 203- 230.

Karstila, T., Rechardt, L., Honkaniemi, J., Gustafsson, J. - $\AA$., Wikströms, A. -C., Karppinen, A., and Pelto-Huikko, M. 1994. Immunocytochemical localization of glucocorticoid receptor in rat skin. Histochemistry, 102: 305-309.

Ke, F. -C. and Ramirez, V.D. 1990. Binding of progesterone to nerve cell membranes of rat brain using progesterone conjugated to ${ }^{125}$ I-bovine serum albumin as a ligand. J. Neurochem., 54: 467-472.

Kimura, N., Mizokami, A., Oonuma, T., Sasano, H., and Nagura, H. 1993. Immunocytochemical localization of androgen receptor with polyclonal antibody in paraffin-embedded human tissues. J. Histochem. Cytochem., 41: 671-678.

Kosugi, I., Muro, H., Shirasawa, H., and Ito, I. 1992. Endocytosis of soluble IgG immune complex and its transport to lysosomes in hepatic sinusoidal endothelial cells. J. Hepatol., 16: 106-114.

Kuhn, R.W. 1988. Corticosteroid-binding globulin interactions with target cells and plasma membranes. Ann. N.Y. Acad. Sci, 538: 146-158.

Liang, T., Hoyer, S., Yu, R., Soltani, K., Lorincz, A.L., Hiipakka, R.A., and Liao, S. 1993. Immunocytochemical localization of androgen receptors in human skin using monoclonal antibodies against the androgen receptor. J. Invest. Dermatol., 100: 663-666.

Limet, J. N., Quintart, J., Schneider, Y. -J., and Courtoy, P.J. 1985. Receptor-mediated endocytosis of polymeric IgA and galactosylated serum albumin in rat liver. Evidence for intracellular ligand sorting and identification of distinct endosomal compartments. Eur. J. Biochem., 146: 539-548.

Liposits, Zs. and Bohn, M.C. 1993. Association of glucocorticoid receptor immunoreactivity with cell membrane and transport vesicles in hippocampal and hypothalamic neurons of the rat. J. Neurosci. Res., 35: 14-19.

Long, R.G., McAfee, J.G., and Winkelman, J. 1963. Evaluation of radioactive compounds for the external detection of cerebral tumors. Cancer Res., 23: 98-108.

Madan, A.P. and DeFranco, D.B. 1993. Bidirectional transport of 
glucocorticoid receptors across the nuclear envelope. Proc. Natl. Acad. Sci. USA, 90: 3588-3592.

Mangelsdorf, D.J., Thummel, C., Beato, M., Herrlich, P., Schütz, G., Umesono, K., Blumberg, B., Kastner, P., Mark, M., Chambon, P., and Evans, R.M. 1995. The nuclear receptor superfamily: The second decade. Cell, 83: 835-839.

Mego, J.L., Bertini, F., and McQueen, J.D. 1967. The use of formaldehyde-treated ${ }^{125} \mathrm{I}$-albumin in the study of digestive vacuoles and some properties of these particles from mouse liver. J. Cell Biol., 32: 699-707.

Mendel, C. M. 1992. The free hormone hypothesis. Distinction from the free hormone transport hypothesis. J. Androl., 13: 107-116.

Murtazaeva, L.A., Khamidov, D. Kh., Baibekov, I. M., and Babich, G.V. 1978. Electron microscope autoradiography of the liver after administration of corticosterone- ${ }^{3}$ H. Biull. Eksp. Biol. Med., 85: 608-610.

Nilsson, M. and Berg, T, 1977. Uptake and Degradation of formaldehydetreated ${ }^{125}$ I-labeled human serum albumin in rat liver cells in vivo and in vitro. Biochim. Biophys. Acta, 497: 171-182.

Nishimura, T., Kawai, N., and Ichihara, I. 1991. Interaction of endocytotic vacuoles with the inner nuclear membrane in simian virus 40 entry into CV-1 cell nucleus. Cell Struct. Funct., 16: 441-445.

Nishimura, T. and Ichihara, I. 1997. Nuclear concentration of gold labeledtestosterone-bovine serum albumin conjugate injected intravenously in the hormone-target cells of rat. Cell Struct. Funct., 22: 433-442.

Nishimura, T. and Nakano, T. 1997. Nuclear translocation of gold labeledtestosterone-bovine serum albumin conjugate through the nuclear double membranes in rat spermatids. Cell Struct. Funct., 22: 621-629.

Nishimura, T. and Nakano, T. 1999. Nuclear localization of gold labeledhydrocortisone-bovine serum albumin conjugate injected intravenously into the hormone-target cells of rat. Cell Struct. Funct., 24: 227-235.

Norfleet, A.M., Thomas, M.L., Gametchu, B., and Watson, C.S. 1999. Estrogen receptor- $\alpha$ detected on the plasma membrane of aldehydefixed $\mathrm{GH}_{3} / \mathrm{B} 6 / \mathrm{F} 10$ rat pituitary tumor cells by enzyme-linked immunocytochemistry. Endocrinology, 140: 3805-3814.

Okuda, Y., Hashimoto, K., Nakayama, M., and Yamamoto, H. 1989. Histochemical study on androgen receptor in canine testis by an androgen labeled with colloidal gold. J. Nara Med. Assoc., 40: 625-629.

Olkkonen, V.M. and Stenmark, H. 1997. Role of Rab GTPases in membrane traffic. Int. Rev. Cytol., 176: 1-85.

Owen, N.C., Immelman, A., and Grib, D. 1975. The elimination of albumin, polyvinylpyrrollidone and dextran from the circulation in sheep. J. S. Afr. Vet. Assoc., 46: 245-247.

Pardridge, W.M. 1988. Selective delivery of sex steroid hormones to tissues in vivo by albumin and by sex hormone-binding globulin. Ann. N.Y. Acad. Sci., 538: 173-192.

Pertschuk, L.P., Tobin, E.H., Tanapat, P., Gaetjens, E., Carter, A.C., Bloom, N.D., Macchia, R.J., and Eisenberg, K.B. 1980. Histochemical analyses of steroid hormone receptors in breast and prostatic carcinoma. $J$. Histochem. Cytochem., 28: 799-810.

Pescovitz, O.H., Cutler Jr., G.B., and Loriaux, D.L. 1990. Synthesis and secretion of corticosteroids. In Principles and Practice of Endocrinology and Metabolism. (K.L. Becker, ed.). J.B. Lippincott Company, Philadelphia, pp. 579-591.

Pietras, R.J. and Szego, C.M. 1984. Specific internalization of estrogen and binding to nuclear matrix in isolated uterine cells. Biochem. Biophys. Res. Commun., 123: 84-91.

Raddatz, D., Henneken, M., Armbrust, T., and Ramadori, G. 1996. Subcellular distribution of glucocorticoid receptor in cultured rat and human liver-derived cells and cell lines: Influence of dexamethasone. Hepatology, 24: 928-933.

Ramadori, G., Knittel, T., Schwögler, S., Bieber, F., Rieder, H., and Meyer zum Büschenfelde, K. -H. 1991. Dexamethasone modulates $\alpha_{2}$ macroglobulin and apolipoprotein $\mathrm{E}$ gene expression in cultured rat liver fat-storing (Ito) cells. Hepatology, 14: 875-882.
Rao, B.R., Patrick, T.B., and Sweet, F. 1980. Steroid-albumin conjugate interaction with steroid-binding proteins. Endocrinology, 106: 356-362.

Revelli, A., Massobrio, M., and Tesarik, J. 1998. Nongenomic actions of steroid hormones in reproductive tissues. Endocrine Rev., 19: 3-17.

Rosner, W., Hryb, D.J., Khan, M.S., Singer, C.J., and Nakhla, A.M. 1988. Are corticosteroid-binding globulin and sex hormone-binding globulin hormones? Ann. N.Y. Acad. Sci., 538: 137-145.

Rosner, W., Hryb, D.J., Khan, M.S., Nakhla, A.M., and Romas, N.A. 1999. Androgen and estrogen signaling at the cell membrane via G-proteins and cyclic adenosine monophosphate. Steroids, 64: 100-106.

Rossato, M., Nogara, A., Merico, M., Ferlin, A., and Foresta, C. 1999. Identification of functional binding sites for progesterone in rat Leydig cell plasma membrane. Steroids, 64: 168-175.

Rothman, J.E. and Wieland, F.T. 1996. Protein sorting by transport vesicles. Science, 272: 227-234.

Sar, M., Liao, S., and Stumpf, W.E. 1970. Nuclear concentration of androgens in rat seminal vesicles and prostate demonstrated by drymount autoradiography. Endocrinology, 86: 1008-1011.

Sar, M., Stumpf, W.E., McLean, W.S., Smith, A.A., Hansson, V., Nayfeh, S. N., and French, F.S. 1975. Localization of androgen target cells in the rat testis: Autoradiographic studies. Curr. Top. Mol. Endocrinol., 2: 311319.

Schultz, R., Isola, J., Parvinen, M., Honkaniemi, J., Wikström, A. -C., Gustafsson, J. -Å., and Pelto-Huikko, M. 1993. Localization of the glucocorticoid receptor in testis and accessory sexual organs of male rat. Mol. Cell. Endocrinol., 95: 115-120.

Selcer, K.W. and Leavitt, W.W. 1988. Hamster uterine tissues accumulate corticosteroid-binding globulin during decidualization. Biol. Reprod., 39: 592-602.

Shaskas, J.R. and Bottoms, G.D. 1974. Intranuclear binding of hydrocortisone in liver and thymus tissues. Proc. Soc. Exp. Biol. Med., 147: 232-238.

Strømhaug, P.E., Berg, T.O., Gjøen, T., and Seglen, P.O. 1997. Differences between fluid-phase endocytosis (pinocytosis) and receptor-mediated endocytosis in isolated rat hepatocytes. Eur. J. Cell Biol., 73: 28-39.

Suyemitsu, T. and Terayama, H. 1975. Specific binding sites for natural glucocorticoids in plasma membranes of rat liver. Endocrinology, 96: 1499-1508.

Szego, C.M., Steadman, R.A., and Seeler, B.J. 1974. Intranuclear concentration of lysosomal hydrolases in steroid target cells. Acute response to administration of gonadal hormones in vivo. Eur. J. Biochem., 46: $377-$ 386.

Szego, C.M. 1984. Mechanisms of hormone action: Parallels in receptormediated signal propagation for steroid and peptide effectors. Life Science, 35: 2383-2396.

Takami, M., Kasuya, I., and Tsunoo, H. 1992. Polymerized albumin receptor on rat liver cells. J. Biochem., 111: 714-721.

Truebe, M., Ibarrola, I., Ogiza, K., Marino, A., and Macarulla, J.M. 1991. Specific binding sites for corticosterone in isolated cells and plasma membrane from rat liver. J. Membrane Biol., 120: 115-124.

Van Dyke, R.W. and Root, K.V. 1993. Ethinyl estradiol decreases acidification of rat liver endocytic vesicles. Hepatology, 18: 604-613.

Wake, K. 1980. Perisinusoidal stellate cells (fat-sorting cells, interstitial cells, Lipocytes), their related structure in and around the liver sinusoids, and vitamin A-sorting cells in extrahepatic organs. Int. Rev. Cytol., 66: 303-353.

Watson, C. S. and Gametchu, B. 1999. Membrane-initiated steroid actions and the proteins that mediate them. Proc. Soc. Exp. Biol. Med., 220: 9 19.

Watson, C.S., Norfleet, A.M., Pappas, T.C., and Gametchu, B. 1999. Rapid actions of estrogens in $\mathrm{GH}_{3} / \mathrm{B} 6$ pituitary tumor cells via a plasma membrane version of estrogen receptor- $\alpha$. Steroids, 64: 5-13.

Wehling, M. 1997. Specific, nongenomic actions of steroid hormones. 
Annu. Rev. Physiol., 59: 365-393.

Yokota, S. and Fahimi, H.D. 1987. Uptake of formalin-denaturated albumin by the sinus-lining cells of rat liver: An immunocytochemical and cytochemical study. Cell Struct. Funct., 12: 295-309.

Yoshioka, T., Yamamoto, K., Kobashi, H., Tomita, M., and Tsuji, T. 1994. Receptor-mediated endocytosis of chemically modified albumins by sinusoidal endothelial cells and Kupffer cells in rat and human liver. Liver, 14: 129-137.

(Received for publication, March 7, 2000

and in revised form, April 10, 2000) 